\title{
Morphological and Molecular Characterization of Some Wild and Cultured Clarias (Clariidae, Siluriformes) Fish Species from Cameroon
}

\author{
Geneva Ojong Nkongho ${ }^{1,2^{*}}$, Benedicta Oshuware Oben ${ }^{1}$, Muyideen Timothy Sanni ${ }^{3}$, Olubunmi \\ T. Agbebi ${ }^{4}$, Atkin Egbe Obie ${ }^{5}$, Judith Georgette Makombu ${ }^{1}$, Ambeno Fidelis Narika ${ }^{1}$, Mbeng \\ Ashu Arrey ${ }^{1}$ and Pius Mbu Oben ${ }^{1}$ \\ ${ }^{1}$ Department of Fisheries and Aquatic Resources Management, Faculty of Agriculture and Veterinary Medicine, \\ University of Виеа, Вuеa, Cameroon. \\ ${ }^{2}$ Institute of Agricultural Research for Development, Kribi, Cameroon. \\ ${ }^{3}$ Department of Animal Breeding and Genetics, Federal University of Agriculture, Abeokuta, Ogun State, \\ Nigeria. \\ ${ }^{4}$ Department of Aquaculture and Fisheries Management, Federal University of Agriculture, Abeokuta, Ogun \\ State, Nigeria. \\ ${ }^{5}$ Epsilon Environnement, Kribi, Cameroon.
}

*Corresponding Author: Geneva Ojong Nkongho, Department of Fisheries and Aquatic Resources Management, Faculty of Agriculture and Veterinary Medicine, University of Buea, Buea, Cameroon.

\begin{abstract}
Wild Clarias fish species are used for aquaculture in Cameroon, but information on their characterization is limited and mislabelling is rife. The purpose of this study was therefore to characterize wild and cultured Clarias fish specimens from Cameroon. Twenty-six (26) morphometric features, 3 meristic counts, some morphological observations and the cytochrome oxidase subunit I (COI) gene were used for the characterization. Based on gill raker count $(G R C)$, specimens were separated into two principal groups. One group was tentatively identified as $C$. gariepinus and the second group as $C$. jaensis. However, because of the discrepancy in pectoral spines serration, the second group was referred to as C. aff. jaensis. Clarias gariepinus from Nkam and Mezam Rivers possessed the crescent vomerine while the cultured stock had interrupted vomerine and those from the Mungo River had both forms of vomerine. Based on phylogenetic tree, C. gariepinus from Mungo River was more diverse and ancestral compared to the other populations. Genetic identity of C. aff. jaensis with GenBank references was 92-94\%. So the exact identity of the species remained unclear. Further studies are therefore needed to determine if these sequences represent an isolated branch of $C$. jaensis or if they belong to another species.

Keywords: Cameroon, Characterization, Clarias species, molecular, morphological

Abbreviations: Anal fin length (AFL); Caudal fin length (CFL); Caudal peduncle depth (CPD); Cytochrome oxidase subunit I (COI); Discriminant Analysis (DA); Distance between occipital process and dorsal fin origin $(O P D F)$; Dorsal fin length (DFL); Eye diameter (ED); Frontal fontanel length (FFL); Frontal fontanel width (FFW); Gill raker count (GRC); Head length (HL); Head width (HW); Interorbital distance (IOW); Maximum body depth (MBD); Occipital process length (OPL); Occipital process width (OPW); Pectoral fin length (PEFL); Pectoral spine length (PESL); Pelvic fin length (PFL); Preanal distance (PAL); Predorsal distance (PDL); Premaxillary toothplate width (PMW); Prepectoral distance (PPEL); Prepelvic distance (PPL); Snout length (SNL); Standard length (SL); Total length (TL); Vomerine toothplate width (VMW)
\end{abstract}

\section{INTRODUCTION}

The culture of clariid fishes is gaining grounds globally due to their hardy and air-breathing characteristics, fast growth, high fecundity, fleshy and palatable meat and high economic value [1] and [2]. The African catfish (Clarias gariepinus BURCHELL) is the main cultured species owing to the availability of vast research findings on its biology and aspects of culture [24];[25];[3];[4];[5] and [6]. It is thought to have been introduced to several parts of the world including Cameroon for aquaculture purpose [26].

Presently, C. gariepinus occurs naturally in most rivers of Cameroon sympatrically with other Clarias species [27] and [7]. Although this species is exploited for table fish or for culture system stocking, 
there is a general lack of knowledge on the genetic variability of the different strains farmed in different parts of Cameroon [26].

According to [8], the culture of hybrids without proper genetic and economic evaluation rather invites more problems in the aquaculture sector. Proper identification is very crucial for proper fisheries assessment and management programmes. Effective species identification combines morphological and molecular methods, as some morphological characters/features may be misleading for proper identification and classification, and the molecular approach may rely on the morphological features for the right conclusion to be made, thus the two methods are supplementary to each other [9]. Molecular approach using the mitochondrial cytochrome oxidase subunit I (COI) gene has proved to provide unambiguous species level identification [10]. Therefore, this study reports on the characterization of some wild and cultured Clarias species from Cameroon using both morphological and molecular approaches.

\section{Materials AND Methods}

\subsection{Sample Collection Sites}

The wild Clarias fish specimens were obtained from Mezam River basin (UTM 32N 616245689809 and UTM 32N 618382 689322), Nkam River (UTM 32N 0611297056881 ) and Mungo River (UTM $32 \mathrm{~N} 0546055$ 0472694) found in the North West, West and South West Regions of Cameroon.

\subsection{Field Sampling and Laboratory Procedure}

The wild specimens were randomly captured using active and passive fishing methods. They were transported in plastic tanks, in which they were submerged in little water, to the CORAF/WECARD Fisheries and Aquaculture Laboratory, University of Buea where they were frozen and stored prior to morphological study. Pelvic fins and muscles tissues of live specimens were sampled for molecular analyses. DNA extraction and electrophoresis analysis was carried out at the Biotechnology Centre of the Federal University of Agriculture, Abeokuta, Nigeria and gene sequencing was carried out by MACROGEN Company, USA.

\subsection{Morphological Characterization}

For each of the 125 fish specimens studied, 26 point-to-point morphometric measurments were taken using a Three-Button Digital Caliper $(0-150 \mathrm{~mm}$; to the nearest $0.01 \mathrm{~mm}$ ) and a meter ruler ( to the nearest $0.1 \mathrm{~cm}$ ). The morphometric measurments were taken following a guide reported in [28] as shown in Figures 1a, $1 \mathrm{~b}$ and $1 \mathrm{c}$ for morphometrical identification of Clarias species. The morphometric measurements included: 1) Total length (TL); 2) Standard length (SL); 3) Maximum body depth (MBD); 4) Caudal peduncle depth (CPD); 5) Head length (HL); 6) Head width (HW); 7) Snout length (SNL); 8) Interorbital distance (IOW); 9) Eye diameter (ED); 10) Occipital process length (OPL); 11) Occipital process width (OPW); 12) Frontal fontanel length (FFL); 13) Frontal fontanel width (FFW); 14) Premaxillary toothplate width (PMW); 15) Vomerine toothplate width (VMW); 16) Predorsal distance (PDL); 17) Preanal distance (PAL); 18) Prepelvic distance (PPL); 19) Prepectoral distance (PPEL); 20) Dorsal fin length (DFL); 21) Distance between occipital process and dorsal fin origin (OPDF); 22) Pectoral spine length (PESL); 23) Pectoral fin length (PEFL); 24) Pelvic fin length (PFL); 25) Anal fin length (AFL); 26) Caudal fin length (CFL). The meristic measurements taken included: 1) Gill raker count (GRC) which represents the number of gill rakers on the first gill arch; 2) Number of dorsal fin ray; 3) Number of anal fin rays. Morphological observations were made namely 1) Shape of the vomerine toothplate; 2) Shape of the frontal fontanel; 3) Neuromasts (white dots) arrangement pattern on flank; 4) Serration of the pectoral spine; 5) Live specimen colouration.

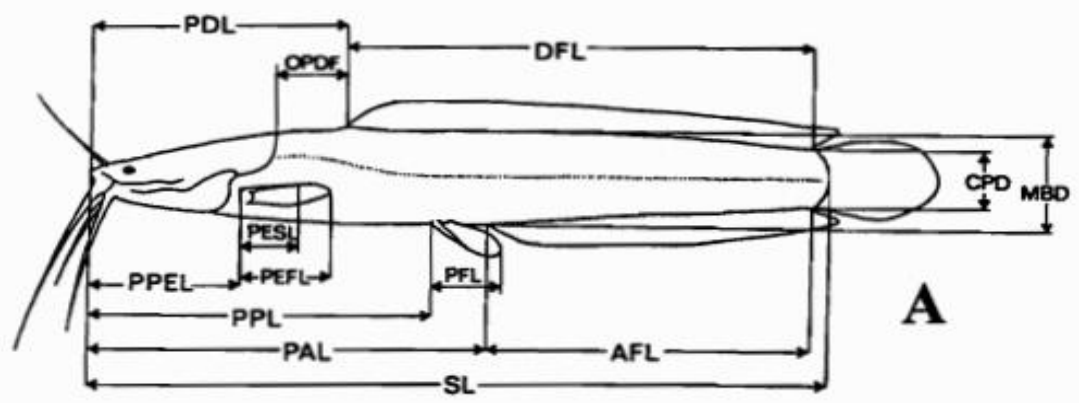



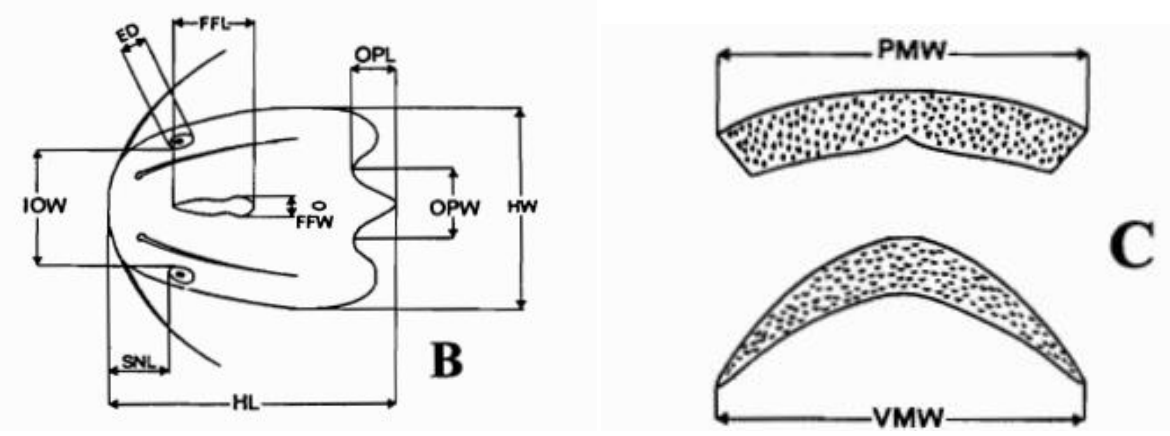

Figures1. Body measurement (A), Head measurement (B) and Toothplates (C)

Source: Teugels et al. (1998)

\subsection{Molecular Analyses}

Following morphological characterization, pelvic fin and muscle tissues were excised from each three to twelve live fish specimens per population. Tissues were preserved in $96 \%$ ethanol [11]. The ratio of tissue to preservative was at least 1:5 weight for volume (w/v). The vials were firmly closed and stored at room temperature. A few days (not later than a month) after tissue collection, vials were recharged with fresh ethanol and taken to the Federal University of Agriculture, Abeokuta, Nigeria, where upon arrival storage was continued in the fridge at the Biotechnology Laboratory of the University.

DNA extracts were prepared from preserved tissues using QIAGEN DNeasy ${ }^{\circledR}$ Blood and Tissue kit following the manufacturer's instructions. The concentration of the double stranded DNA and extract purity were checked spectrophotometrically [10] using a Thermo Fisher Scientific Nanodrop Lite spectrophotometer.

Fifteen (15) $\mu \mathrm{L}$ PCR reaction mixes including $7.5 \mu \mathrm{L}$ of Norgen's $2 \mathrm{X}$ PCR master mix, $0.75 \mu \mathrm{L}$ of each primer $(3.0 \mu \mathrm{M}), 2 \mu \mathrm{L}$ of template DNA $(25 \mathrm{ng} / \mu \mathrm{L})$ and $4 \mu \mathrm{L}$ of nuclease free water were prepared. Primers used were designed by [12] and synthesized by Integrated DNA Technology (IDT), Canada. The primer sequences are:

Forward primer - 5'TCAACCAACCACAAAGACATTGGCAC3'

Reverse primer - 5'ACTTCAGGGTGACCGAAGAATCAGAA3'

The PCR process was carried out using the Multigene optimax thermocycler (Applied Biosystem California, USA). The thermocycle regime consisted of 2 minutes of initial denaturation at $94{ }^{\circ} \mathrm{C}$, followed by 40 cycles of 0.5 minute of denaturation at $94{ }^{\circ} \mathrm{C}, 0.5$ minute of annealing at $59{ }^{\circ} \mathrm{C}, 2$ minutes of extension at $72{ }^{\circ} \mathrm{C}, 5$ minutes final extention at $72{ }^{\circ} \mathrm{C}$ and then held at $4{ }^{\circ} \mathrm{C}$. The PCR products were then run on $1 \%$ agarose gel stained with ethidium bromide dye $(17 \mu \mathrm{L} / 100 \mathrm{~mL}$ gel $)$ and bands were visualized using a Digigel-Advanced gel documentation system possessing an embedded Canon Camera. PCR amplicon was sequenced bi-directionally following the Sanger sequencing method by MACROGEN Company, Maryland, USA.

The sequences were blasted in GenBank to get database matches using the NCBI website (https://www.ncbi.nlm.nih.gov). Sequences were aligned and evolutionary analyses conducted using the Molecular Evolutionary Genetics Analysis (MEGA) version 6 [13]. All positions containing gaps and missing data were eliminated. Evolutionary distances were computed using the Poisson correction method and the evolutionary history was inferred using the Neighbour-Joining (NJ) tree method of [14]. To determine the measure of support for a node, bootstrapping was performed with 1000 replications.

Cytochrome oxidase subunit I amino acid sequences of Arius maculatus (spotted catfish) with accession number W5XIT4 was retrieved from the Universal Protein Resources (UniProt) database after database search using C. gariepinus sequence and included in the phylogeny as a suitable outgroup.

\subsection{Data Analysis}

Morphometric indices for $C$. gariepinus and specimens tentatively identified as $C$. jaensis were computed in Microsoft Excel. Morphometric and meristic measurements were subjected to 
multivariate analysis based on the Discriminant Analysis (DA) using SPSS version 20 statistical package to predict group membership.

\section{RESULTS AND DISCUSSIONS}

\subsection{Morphological Analysis}

The one hundred and twenty-five (125) specimens examined were grouped into two groups based mainly on their GRC. In group 1 of 86 specimens, 45-87 gill rakers were recorded for specimens with SL ranging from 213-632 mm and in group 2 of 39 specimens, 13-19 gill rakers were recorded for specimens with SL ranging from 172-366 mm. Based on the GRC for Clarias species, the former group was identified as $C$. gariepinus and the latter group as $C$. jaensis [22]. However, unlike the one side serration [22] or strong serration on the anterior side with a few spines at the distal end of the posterior side [23] earlier reported for $C$. jaensis, the pectoral spines of specimens tentatively identified as $C$. jaensis were strongly serrated on both sides as shown in Figure 2, although the fish shared some morphological similarity with $C$. jaensis. Thus they were referred to as $C$. aff. jaensis. Further studies may be able to clarify the reason for the differences. The scatter plot of gill raker count against standard length for the two species is presented in Figure 3.

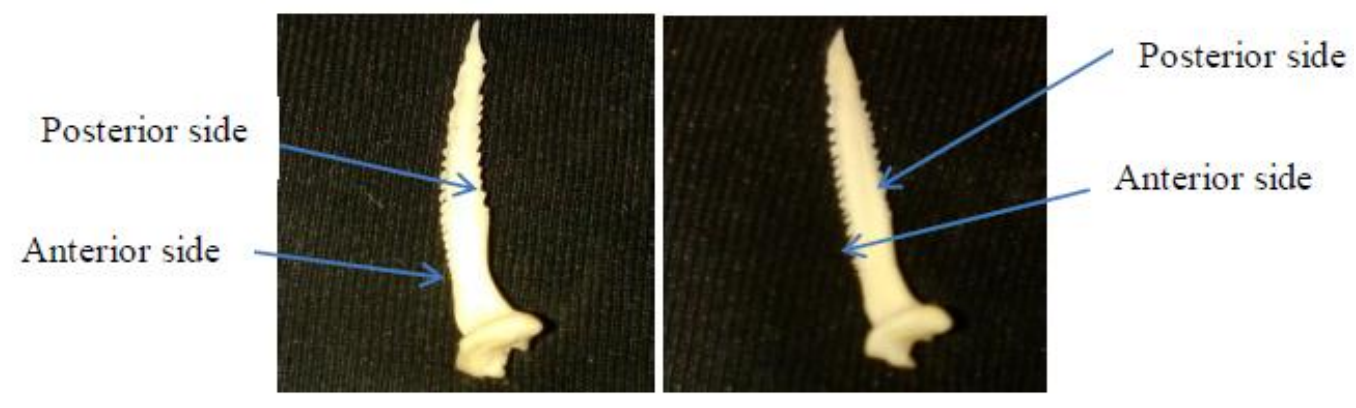

Figure2. Pectoral spine serration pattern observed for specimens tentatively identified as $C$. jaensis

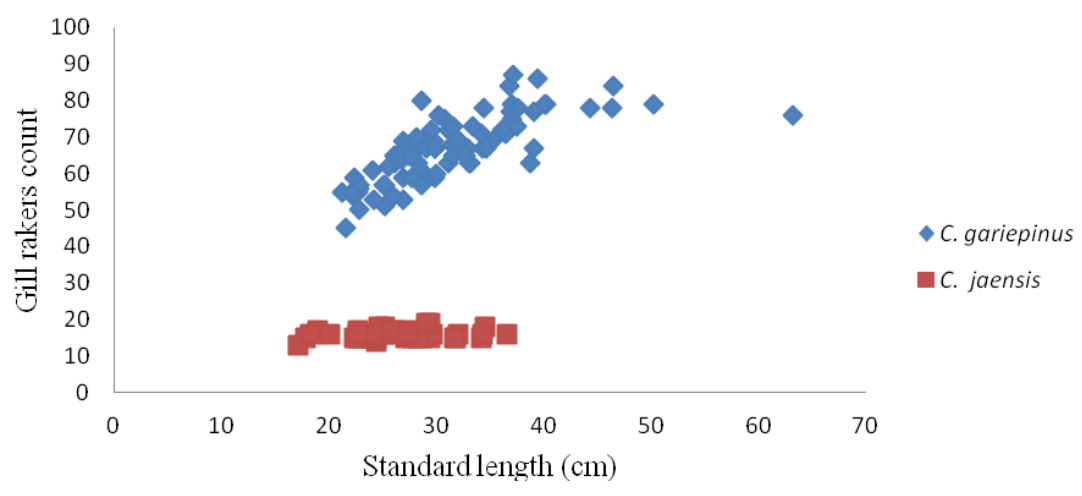

Figure3. A scatter plot of gill raker count against standard length for C. gariepinus and specimens tentatively identified as $C$. jaensis

Variable forms of vomerine toothplate were observed for specimens of $C$. gariepinus as earlier reported by [15]. Based on the nature of the vomerine toothplate, C. gariepinus specimens were separated into two groups; those with vomerine toothplates that are interrupted in the middle (specimens from Mungo River and those from a private farm) (Figure 4a - 4d)) and those with crescent vomerine toothplates (specimens from Rivers Mezam and Nkam) (Figures 4e and 4f). Both types of vomerine were only observed among specimens from the Mungo River. According to [15], variation in vomerine toothplate is probably due to many factors, one being the age (or size) of the fish. However, the vomerine toothplate transformation whereby the interrupted vomerine toothplate in younger fish is gradually transformed to the crescent shape [15] was not observed in this study since interrupted vomerine of farmed fish (age four months) did not transform to crescent shaped vomerine after four additional months in culture in the same farm.

The interrupted vomerine toothplate observed particularly in the specimens from the farm (SL from 222 to $395 \mathrm{~mm}$ ) could be as a result of adaptation. According to [16], decades of introduction and 
domestication of a fish species (especially those from the wild) leads to high adaptation to a wide range of geographical locations, which leads to phenotypic variations with respect to the pure stocks. According to [17], morphometric differences observed between the cultured and wild African catfish could be linked to genetic differences or environmental factors or a combination of both factors.

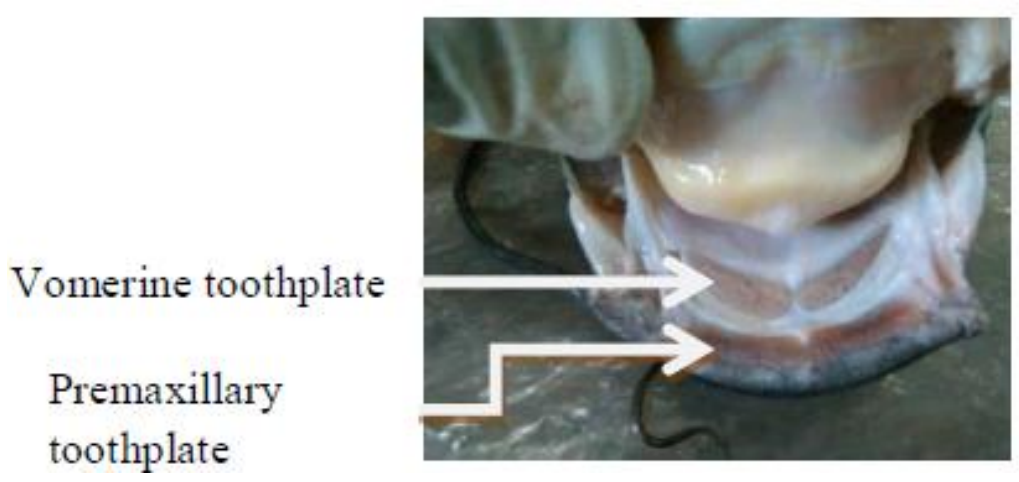

Figure4a. Interrupted vomerine toothplate: C. gariepinus from Mungo River

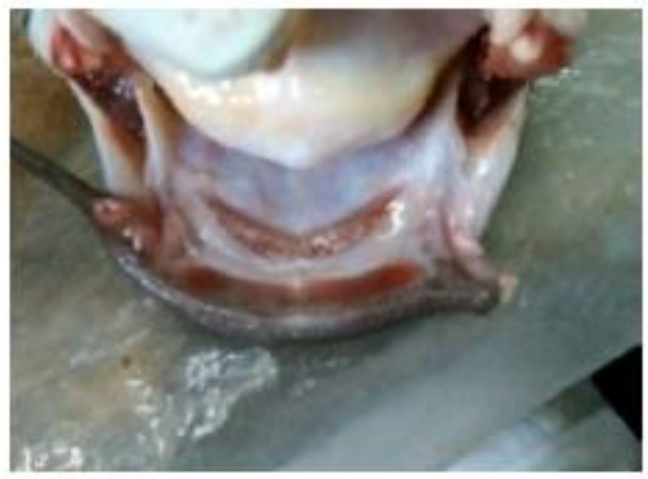

Figure4b. Vomerine toothplate narrows thinly in the middle: C. gariepinus from Mungo River

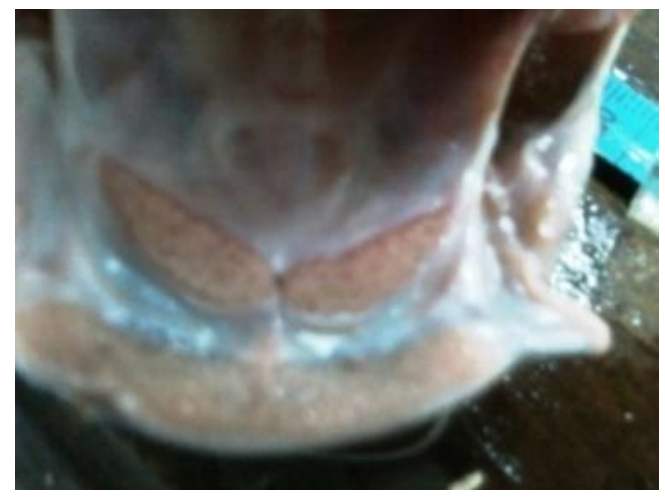

Figure4c. Interrupted vomerine toothplate: C. gariepinus specimen from a private fish farm

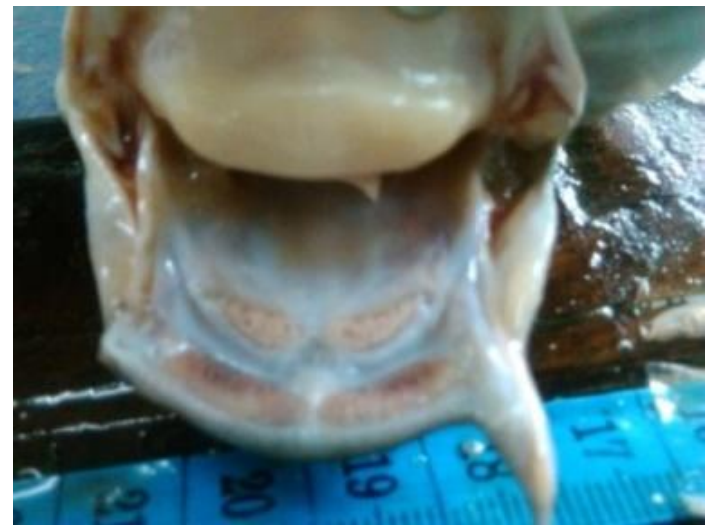

Figure4d. Interrupted vomerine toothplate: C. gariepinus specimen from a private fish farm 


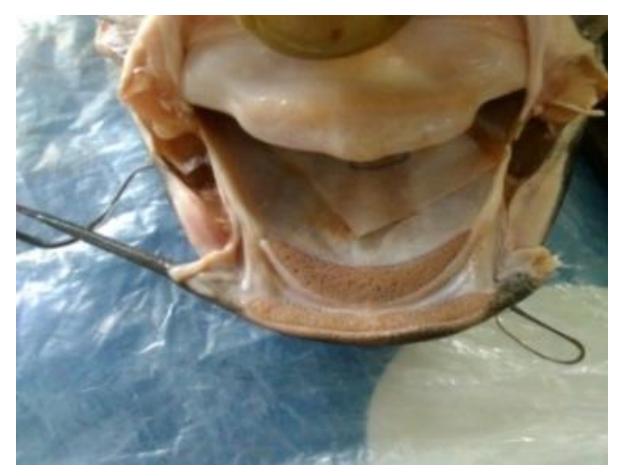

Figure4e. Crescent vomerine toothplate: C. gariepinus specimen from Mezam River

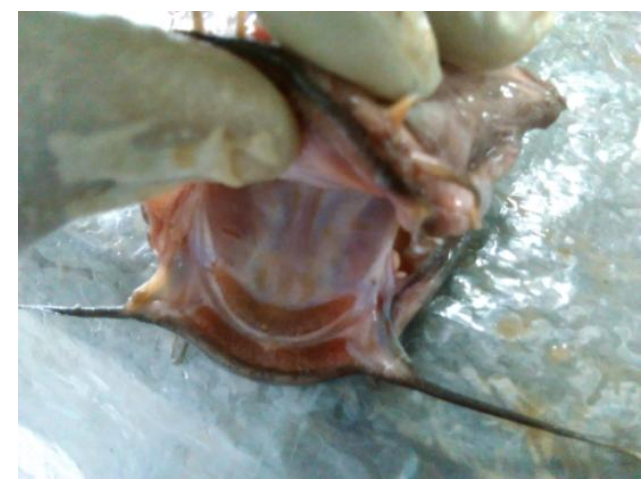

Figure4f. Crescent vomerine toothplate: C. gariepinus specimen from Nkam River

All C. gariepinus specimens had marble coloured flanks (Figures 5a and 5b) with white ventral regions while $C$. aff. jaensis specimens from the same habitat (specimens were found only in Nkam River) showed several flank colouration (black, brown or marble) as shown in Figures 6 (a, b and c). Frontal fontanels observed in specimens of $C$. gariepinus were longer while those in $C$. aff. jaensis were shorter and broader. However, due to the fact that specimens of $C$. gariepinus from all sampled sites differed mainly in the form of vomerine toothplate possessed, this feature was used to separate them into two groups for morphometric indices computation, while specimens of $C$. aff. jaensis were treated as a third group as shown in Table 1.

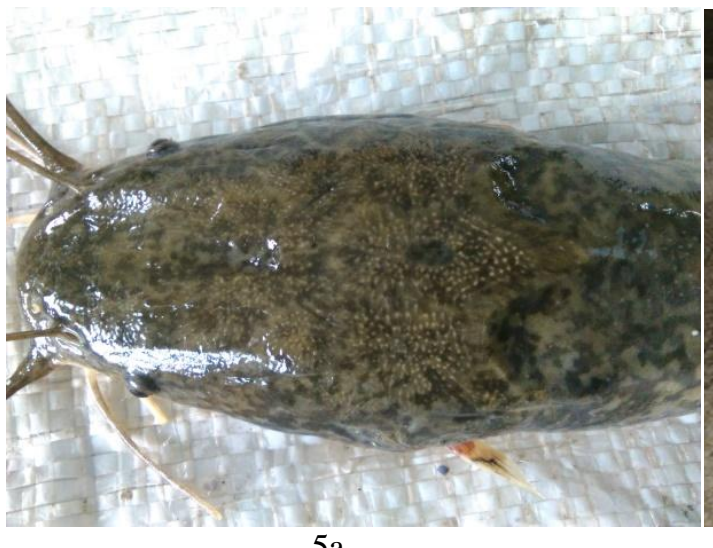

$5 a$

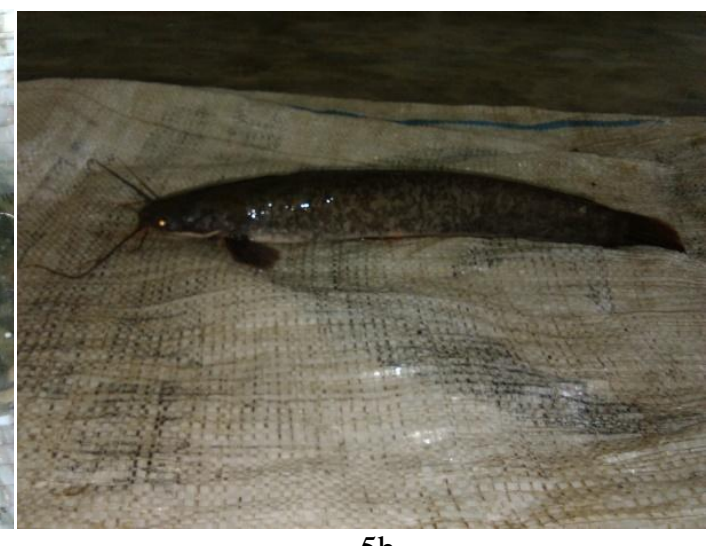

$5 b$

Figure5. Head (a). and flank (b) colouration for live specimens of C. gariepinus examined

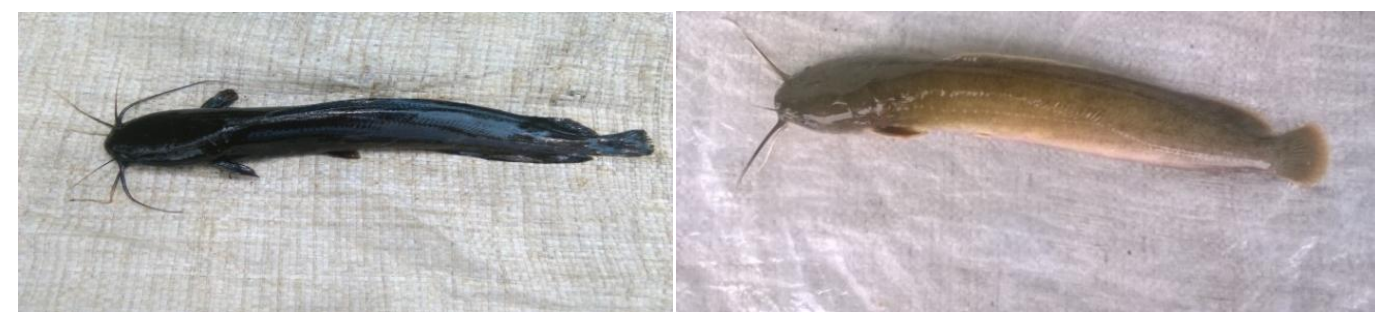

Figure6a. Black dorsal and flank regions

Figure6b. Brown dorsal and flank regions 
Morphological and Molecular Characterization of Wild and Cultured Clarias (Clariidae, Siluriformes) Fish Species from Cameroon

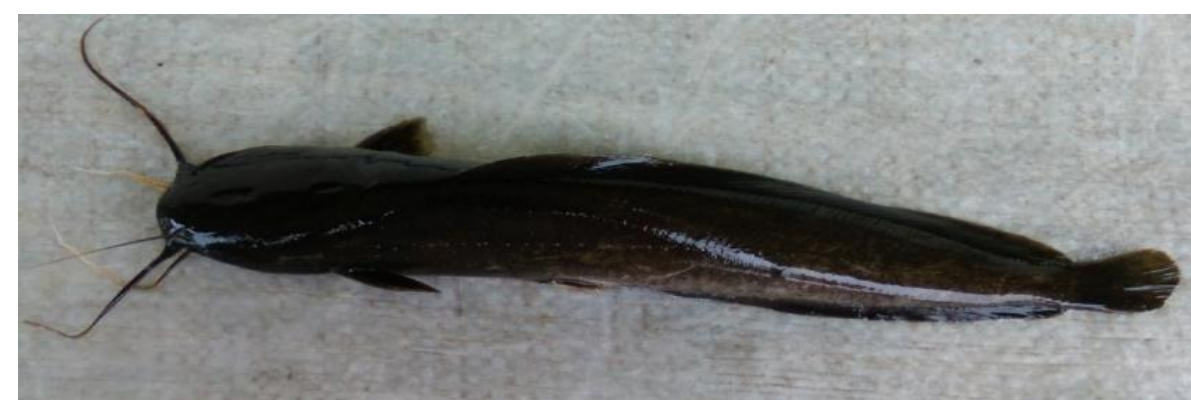

Figure6c. Slightly marbled coloured dorsal and flank regions

Table1. Morphometric data and indices for C. gariepinus with different vomerine forms and specimens tentatively identified as $C$. jaensis from Cameroon

\begin{tabular}{|c|c|c|c|}
\hline Feature & $\begin{array}{l}\text { C. gariepinus from } \\
\text { Mezam and Nkam } \\
\text { Rivers }\end{array}$ & $\begin{array}{l}\text { C. gariepinus from Mungo } \\
\text { and private farm }\end{array}$ & $\begin{array}{l}\text { C. aff. jaensis from } \\
\text { Nkam River }\end{array}$ \\
\hline $\begin{array}{c}\text { Standard length (SL) } \\
(\mathrm{mm})\end{array}$ & $298 \pm 50.91(213-465)$ & $345.55 \pm 94.30(222-632)$ & $264.8 \pm 47.6(172-360)$ \\
\hline $\begin{array}{l}\text { Maximum body depth } \\
(\% \mathrm{SL})\end{array}$ & $\begin{array}{c}13.59 \pm 0.83 \\
(11.24-16.09)\end{array}$ & $\begin{array}{c}12.87 \pm 1.33 \\
(10.55-15.62)\end{array}$ & $\begin{array}{c}15.79 \pm 1.09 \\
(13.18-18.65)\end{array}$ \\
\hline Head length (\%SL) & $\begin{array}{c}30.36 \pm 1.15 \\
(27.37-32.80)\end{array}$ & $\begin{array}{c}30.28 \pm 1.62 \\
(25.79-32.18)\end{array}$ & $\begin{array}{c}25.90 \pm 0.82 \\
(23.98-27.49)\end{array}$ \\
\hline Head width (HW) (mm) & $\begin{array}{c}55.20 \pm 8.45 \\
(40.49-76.24)\end{array}$ & $\begin{array}{c}63.40 \pm 16.60 \\
(42.04-115.08)\end{array}$ & $\begin{array}{c}49.97 \pm 8.63 \\
(33.63-68.62)\end{array}$ \\
\hline Head width (\%HL) & $\begin{array}{c}61.23 \pm 1.67 \\
(57.14-64.37)\end{array}$ & $\begin{array}{c}60.90 \pm 2.46 \\
(55.52-65.36)\end{array}$ & $\begin{array}{l}72.28 \% \pm 2.11 \\
(67.92-77.23)\end{array}$ \\
\hline Predorsal length $(\%$ SL) & $\begin{array}{c}34.77 \pm 1.52 \\
(29.76-37.73)\end{array}$ & $\begin{array}{c}34.77 \pm 1.24 \\
(31.97-36.85)\end{array}$ & $\begin{array}{c}34.41 \pm 0.79 \\
(32.03-35.75)\end{array}$ \\
\hline Preanal length (\%SL) & $\begin{array}{c}52.25 \pm 1.58 \\
(47.35-55.14)\end{array}$ & $\begin{array}{c}52.19 \pm 1.12 \\
(49.48-54.40)\end{array}$ & $\begin{array}{c}48.26 \pm 1.00 \\
(45.36-49.75)\end{array}$ \\
\hline Prepelvic length (\%SL) & $\begin{array}{c}46.64 \pm 1.80 \\
(41.51-53.02)\end{array}$ & $\begin{array}{c}46.72 \pm 1.27 \\
(43.43-48.87)\end{array}$ & $\begin{array}{c}43.52 \pm 1.29 \\
(40.67-46.32)\end{array}$ \\
\hline $\begin{array}{l}\text { Prepectoral length } \\
(\% \mathrm{SL})\end{array}$ & $\begin{array}{c}21.55 \pm 1.04 \\
(19.53-23.86)\end{array}$ & $\begin{array}{c}21.31 \pm 1.87 \\
(15.29-23.65)\end{array}$ & $\begin{array}{c}19.36 \pm 0.95 \\
(17.56-21.82)\end{array}$ \\
\hline Dorsal fin length (\%SL) & $\begin{array}{c}63.00 \pm 1.62 \\
(59.98-67.99)\end{array}$ & $\begin{array}{c}63.16 \pm 1.73 \\
(60.56-67.11)\end{array}$ & $\begin{array}{c}65.13 \pm 1.35 \\
(61.15-68.96)\end{array}$ \\
\hline Dorsal fin rays & $\begin{array}{c}70.25 \pm 4.18 \\
(63-83)\end{array}$ & $\begin{array}{c}68.5 \pm 3.08 \\
(64-75)\end{array}$ & $\begin{array}{c}77.31 \pm 4.26 \\
(61-86)\end{array}$ \\
\hline Anal fin length(\%SL ) & $\begin{array}{c}43.23 \pm 1.47 \\
(39.85-46.67)\end{array}$ & $\begin{array}{c}42.98 \pm 1.13 \\
(41.14-45.55)\end{array}$ & $\begin{array}{c}46.73 \pm 1.35 \\
(43.85-50.05)\end{array}$ \\
\hline Anal fin rays & $\begin{array}{c}52.55 \pm 2.71 \\
(47-59)\end{array}$ & $\begin{array}{c}52.23 \pm 3.05 \\
(46-56)\end{array}$ & $\begin{array}{c}60.23 \pm 2.62 \\
(53-65)\end{array}$ \\
\hline $\begin{array}{c}\text { Distance between } \\
\text { occipital process and } \\
\text { dorsal fin origin }(\% \mathrm{SL})\end{array}$ & $\begin{array}{l}5.12 \pm 0.69 \\
(3.79-6.97)\end{array}$ & $\begin{array}{c}5.08 \pm 0.85 \\
(3.73-6.88)\end{array}$ & $\begin{array}{l}8.98 \pm 0.55 \\
(8.02-9.82)\end{array}$ \\
\hline $\begin{array}{l}\text { Inter-orbital width } \\
(\% \mathrm{HL})\end{array}$ & $\begin{array}{c}39.21 \pm 1.16 \\
(36.81-41.98)\end{array}$ & $\begin{array}{c}38.78 \pm 1.35 \\
(37.16-41.57)\end{array}$ & $\begin{array}{c}25.90 \pm 0.82 \\
(23.98-27.49)\end{array}$ \\
\hline $\begin{array}{c}\text { Occipital process length } \\
(\% \mathrm{HL})\end{array}$ & $\begin{array}{c}14.55 \pm 1.63 \\
(10.99-22.26)\end{array}$ & $\begin{array}{c}14.46 \pm 1.41 \\
(11.72-16.60)\end{array}$ & $\begin{array}{c}13.21 \pm 1.15 \\
(10.99-16.03)\end{array}$ \\
\hline $\begin{array}{c}\text { Premaxillary toothplate } \\
\text { width }(\% \mathrm{HL})\end{array}$ & $\begin{array}{c}28.45 \pm 1.10 \\
(26.54-30.69)\end{array}$ & $\begin{array}{c}28.40 \pm 1.54 \\
(25.91-32.35)\end{array}$ & $\begin{array}{c}33.86 \pm 1.24 \\
(31.10-36.47)\end{array}$ \\
\hline $\begin{array}{l}\text { Vomerine toothplate } \\
\text { width }(\% \mathrm{HL})\end{array}$ & $\begin{array}{c}24.69 \pm 1.01 \\
(22.51-27.20)\end{array}$ & $\begin{array}{c}23.22 \pm 1.96 \\
(19.62-28.22)\end{array}$ & $\begin{array}{c}28.87 \pm 0.75 \\
(27.24-30.78)\end{array}$ \\
\hline VMW/PMW & $\begin{array}{c}0.87 \pm 0.03 \\
(0.80-0.95)\end{array}$ & $\begin{array}{c}0.82 \pm 0.05 \\
(0.71-0.90)\end{array}$ & $\begin{array}{c}0.85 \pm 0.04 \\
(0.79-0.94)\end{array}$ \\
\hline
\end{tabular}

\subsection{Discriminant Analysis (DA) of Morphological Data}

Based on DA all specimens were accurately classified into two groups; one including all specimens of $C$. gariepinus and the other those of $C$. aff. jaensis as shown in Figure 7. However, C. gariepinus 
specimens from Mezam (Me) and Nkam (K Cga) Rivers were more similar to each other than they were to the other populations. The DA classified $100 \%$ of C. gariepinus from the private farm (CLP) and Mungo (Mu) River, and C. aff. jaensis (K-Caj) and least classified $87 \%$ of Me and $83 \%$ of $C$. gariepinus from Nkam River (K-Cga) into their original source groups as presented in Table 2. A proportion of $16.7 \%$ of Me were misclassified as K-Cga; $9.3 \%$ of K-Cga were misclassified as Me and 3.7\% of CLP were misclassified as Me. This indicates that these samples are highly divergent from each other, but those of Me and K-Cga were not clearly distinct in the discriminant space.

The GRC, FFL, ED, VWM, HL, CPD, PAL, MBD, AFR and PMW were the most discriminating variables to separate the different species based on their smaller Wilks' lambda values as shown on Table 3. Smaller Wilks' lambda values indicated that the variables were better for the prediction of membership of C. gariepinus or C. jaensis.

\section{Canonical Discriminant Functions}

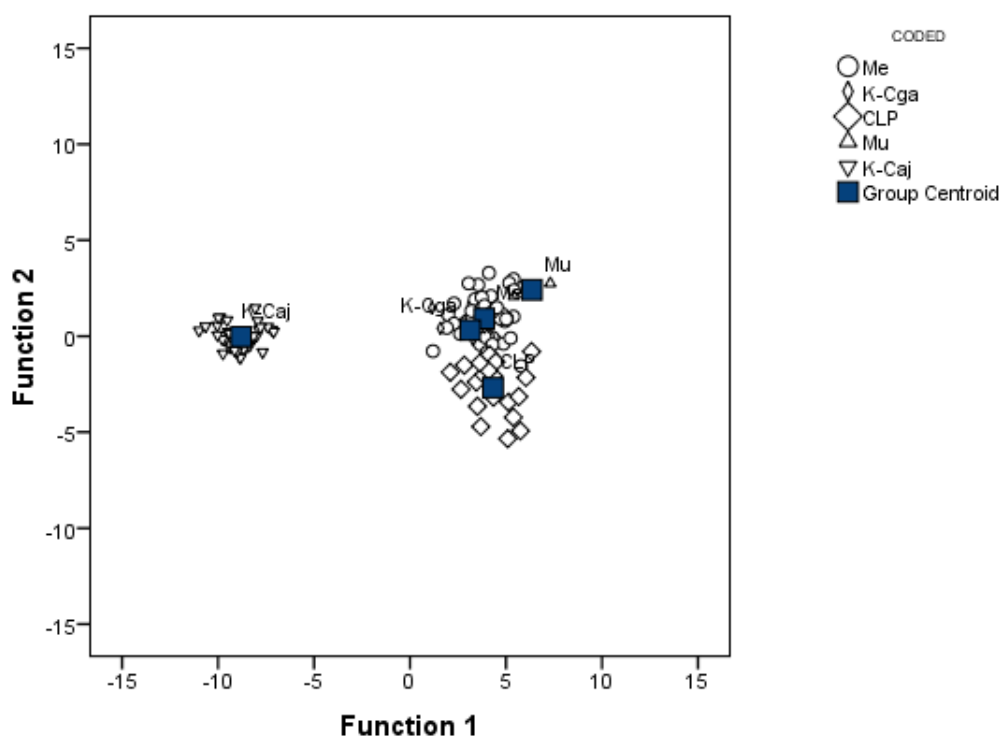

Figure7. Sample centroids of the discriminant function scores based on morphometric and meristic measurements me (C. gariepinus from Mezam River), K-cga (C. gariepinus from Nkam River), $M u(C$. gariepinus from Mungo River), CLP (C. gariepinus from private farm) and $K$-Caj (C. jaensis from Nkam River).

Table2. Percentage of individuals classified into source genetic groups

\begin{tabular}{|c|c|c|c|c|c|c|}
\hline & Me & K-Cga & CLP & Mu & K-Caj & Total \\
\hline $\mathrm{Me}$ & 87 & 9.3 & 3.7 & 0 & 0 & 100 \\
\hline K-Cga & 16.7 & 83.3 & 0 & 0 & 0 & 100 \\
\hline CLP & 0 & 0 & 100 & 0 & 0 & 100 \\
\hline Mu & 0 & 0 & 0 & 100 & 0 & 100 \\
\hline K-Caj & 0 & 0 & 0 & 0 & 100 & 100 \\
\hline
\end{tabular}

Table3. Morphological characters selected by stepwise discriminant analysis to separate the different populations of C. gariepinus and specimens tentatively identified as $C$. jaensis

\begin{tabular}{|c|c|c|c|c|}
\hline Variable & Wilk Lambda & P. level & F to remove & Tolerance \\
\hline NGR & 0.008 & 0.000 & 25.872 & 0.381 \\
\hline FFL & 0.006 & 0.000 & 11.340 & 0.407 \\
\hline ED & 0.005 & 0.000 & 8.900 & 0.324 \\
\hline VMV & 0.006 & 0.000 & 12.729 & 0.040 \\
\hline HL & 0.006 & 0.000 & 12.319 & 0.012 \\
\hline CPD & 0.005 & 0.000 & 7.361 & 0.107 \\
\hline PAL & 0.006 & 0.000 & 12.654 & 0.013 \\
\hline MBD & 0.005 & 0.000 & 6.829 & 0.104 \\
\hline AFR & 0.005 & 0.000 & 4.835 & 0.899 \\
\hline PMW & 0.005 & 0.000 & 4.547 & 0.041 \\
\hline
\end{tabular}




\subsection{Molecular Characterization}

The COI gene of all the thirty studied samples of fish subjected to molecular analysis were amplified with a single primer set (FishF1/FishR2) which gave better results with respect to FishF1/FishR1 used by [18] and the FishF2/FishR2 primer sets. Multiple specimens were used for $C$. gariepinus species because several populations were involved in the analyses. All the $C O I$ gene sequences generated in the forward direction for the specimens morphologically identified as C. gariepinus showed 99-100\% similarity with $C$. gariepinus GenBank references. The sequences of $C O I$ gene for the specimens that were morphologically referred to as $C$. jaensis showed $92 \%$ identity with $C$. jaensis GenBank, but percentage similarity with C. platycephalus and C. dumerilli was $93 \%$ and $94 \%$ with Clariallabes species GenBank references. However, [19] considered a minimum BLAST cut off of $98 \%$ identity for a top match in species identification using BLAST against GenBank barcode for selected taxa. The COI gene sequences of $C$. aff. jaensis species used in this study are closely related and they branched out together on the same clad after the $C$. gariepinus in the phylogenetic tree. The high bootstrap value further indicated their high degree of relatedness.

The phylogenetic tree of the taxa is presented in Figure 8. The percentages of replicates in which the associated taxa clustered together in the bootstrap test are shown next to the branches. It revealed that COI gene sequences of $C$. aff. jaensis all clustered on a reliable bootstrap supported node with confidence of $94 \%$ bootstrap value. They must have diverged more or less later compared to the COI sequences of the $C$. gariepinus which must have diverged earlier and shown obvious differentiation as found in this study.

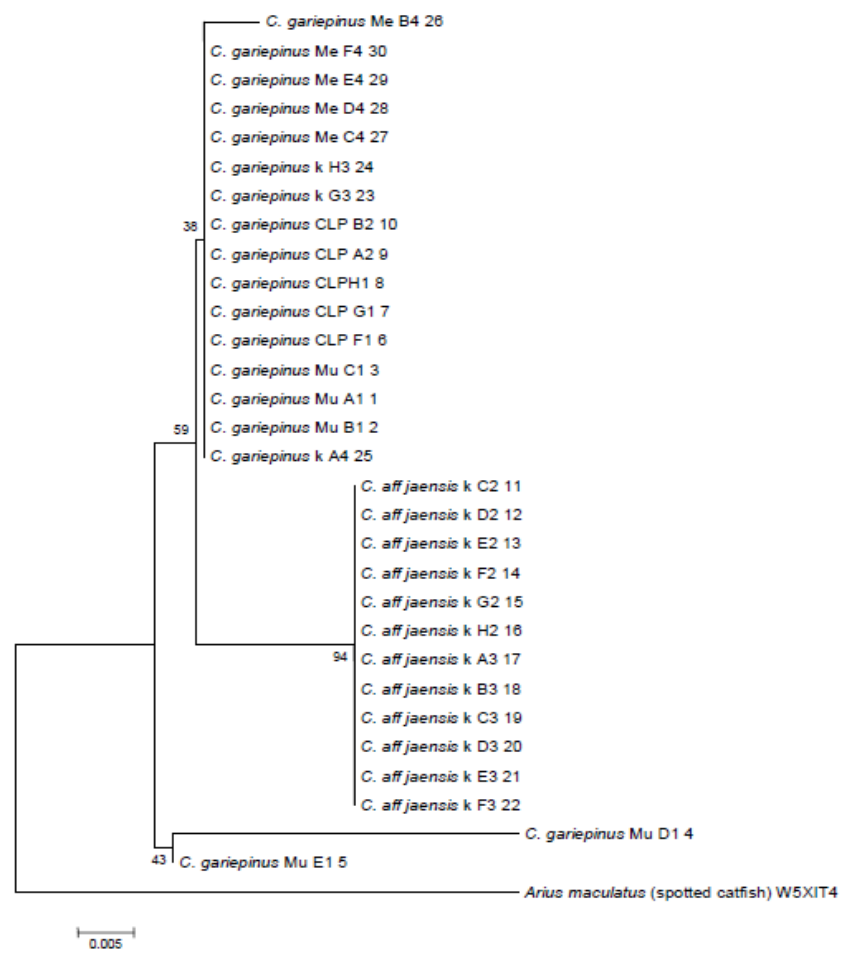

Figure8. Phylogenetic tree of mitochondrial cytochrome oxidase subunit I (COI) gene of catfish species populations using the Neighbour-Joining tree method

Clarias gariepinus from Mezam and Nkam Rivers and the cultured stock are closely related. Two COI gene sequence of $C$. gariepinus from Mungo River are distinctly classified, clustering and branching out at the base of the phylogeny, revealing that they are more ancestral or the wild type to the other COI gene sequences of Clarias specimens used for this study. Aside from these two specimens from Mungo River, all other specimens of $C$. gariepinus clustered together irrespective of the form of vomerine toothplate. Intra-specific divergence has earlier been reported among populations of $C$. gariepinus [18] and populations of other fish species [12]. This divergence could be an indication of varied strains within the species. However, the range for pairwise distance recorded in this study was wider than that reported for clariids species studied by [20], but was within the intraspecific range reported by [12]. [21] suggested that freshwater species show greater mitochondrial 
DNA divergence than marine species. Based on the phylogenetic analysis, it could imply that morphometric variations (varied vomerine toothplate among C. gariepinus) observed in this study may not be linked to genetic difference, but could be attributed mainly to adaptation to environmental factors since the specimens with crescent and interrupted vomerine toothplates clustered together. The COI gene sequence of A. maculates branched at the base of the phylogeny as out-group. As expected, lower evolutionary divergences were observed for intra-specific specimens than for inter-specific specimens. The intra-specific divergence distance ranged from 0.00 to 0.035 compared to 0.121 to 0.170 recorded for the inter-specific.

\section{CONClusion}

The varied vomerine toothplate observed among populations of $C$. gariepinus may not be linked to genetic differences, but to some environmental factors, since specimens clustered together in the phylogenetic tree irrespective of the form of vomerine toothplates. The Mungo River stock is diverse and more or less distinct from the other populations of $C$. gariepinus used in this study and as such, intra-specific cross of this population with the other populations may generate varied gene pools with interesting gene traits for a more sustainable aquaculture. Notwithstanding, the toothplate transformation earlier reported by [15] could be elucidated if the ontogeny of a stock is carefully followed, but this feature may not be an important diagnostic feature for characterization of populations/strains of $C$. gariepinus. In addition, a more detailed study is recommended for the elucidation of the actual identity of specimens tentatively identified as $C$. jaensis.

\section{ACKNOWLEDGEMENT}

We are deeply thankful to the CORAF/WECARD project of the University of Buea for providing materials, storage facilities and working space for the morphological studies. Immense gratitude goes to the Biotechnology Centre of the Federal University of Agriculture Abeokuta, Nigeria for providing equipment, working space and technical assistance for the molecular analyses during the stay of the first author as a Visiting Scholar to their laboratory.

\section{REFERENCES}

[1] Offem B. O., Akegbejo-Samsons Y. and Omoniyi I. T., Aspects of ecology of Clarias anguillaris (Teleostei: Clariidae) in the Cross River, Nigeria, Turk. J. Fish. Aquat. Sci. 10,101-110 (2010).

[2] Oben P. M., Oben B. O., Akoachere R. and Joseph E., Induced spawning, survival and growth of an African catfish hybrid (female Clarias gariepinus and male Clarias angullaris) fingerlings relative to their parental species in the Mount Cameroon Region, Trop. Freshwat. Biol. 24, 63-88 (2015).

[3] Dadebo E., Reproductive biology and feeding habits of the catfish C. gariepinus (Bruchell) (Pisces: Clariidae) in Lake Awassa, Ethiopia, SINET: Ethiop. J. Sci. 23(2), 231-246 (2000).

[4] Brzuska E., Artificial propagation of African catfish (Clarias gariepinus): the application of a single dose of pellets containing D-Ala ${ }^{6}$, Pro $^{9} \mathrm{NEt}-\mathrm{mGnRH}$ and dopamine inhibitor metoclopramide, Czech. J. Anim. Sci. 49(7), 289-296 (2004).

[5] Ibim A. T. and Sikoki F.D., Effect of protein level on gonadal development of the African Catfish, J. Biol. Agric. Health. 4(1), 51-56 (2014).

[6] Sikoki F. D. and Ibim A. T., The Effect of environmental and nutritional manipulation on year-round gonadal development, spawning and recrudescence of female Clarias gariepinus broodfish, Advance. Life Sci. Technol. 6, 1- 9 (2014).

[7] Brummett R. E., Nguenga D., Tiotsop F. and Abina J.-C., The commercial fishery of the middle Nyong River, Cameroon: productivity and the environmental threats, Smithiana Bull. 11,3-16 (2010).

[8] Agbebi O. T., Olufeagba S. O., Mbagwa I. G., Ozoje M. O. and Aremu A., Morphological characteristics and body indices of Heterobranchus bidorsalis from three geographical locations in Nigeria, J. Fish. Int. 4(4), 68-72 (2009).

[9] Friedheim S., Comparison of species identification methods: DNA barcording versus morphological taxonomy, Manoa Horizons 1, 74-86 (2016).

[10] Cawthorn D. - M., Steinman H. A. and Witthuhn R. C., DNA barcoding reveals a high incidence of fish species misrepresentation and substitution on the South African market, Food Res. Int. 4,30-40 (2012).

[11] Zimmermann J., Hajibabaei M., Blackburn D. C., Hanken J., Cantin E., Posfai J. and Evans, T. C. Jr., DNA damage in preserved specimens and tissue samples: a molecular assessment, Front. Zool. doi:10.1186/1742-9994-5-18 (2008) 
[12] Ward, R. D., Zemlak T. S., Innes, B. H., Last, P. R. and Hebert, P. D. N., DNA barcoding Australia's fish species, Philosophic Translations of the Royal Society B 360,1847-1857 (2005).

[13] Tamura K., Stecher G., Peterson D., Filipski A. and Kumar S. MEGA 6: Molecular Evolutionary Genetics Analysis version 6, Mol. Biol. Evol. 30, 2725-2729 (2013).

[14] Saitou N. and Nei M. The neighbor-joining method: A new method for reconstructing phylogenetic trees, Mol. Biol. Evol. 4, 406-425 (1987).

[15] Teugels G. G., Preliminary results of a morphological study of five African species of the subgenus Clarias (Clarias) (pisces; Clariidae), J. Nat. Hist. 16(3),439-464 (1982).

[16] Turan C., Oral M., Ozturk B. and Duzgunes E., Morphometric and meristic variation between stocks of Bluefish (Pomatomus saltatrix) in the black, Marmara, Aegean and Northeasttern Mediterranean Seas, Fish. Res. 79,139-147 (2006).

[17] Solomon S. G., Okomoda V. T. and Ogbenyikwu A. I. Intraspecific morphological variation between cultured and wild Clarias gariepinus (Burchell) (Clariidae, Siluriformes, Archive. Pol. Fish. 23,53-61 (2015).

[18] Falade M. O., Opene A. J. and Benson O., DNA barcoding of Clarias gariepinus, Coptodon zillii and Sarotherodon melanotheron from Southwestern Nigeria, F1000Res. (5)1268,1-14 (2016).

[19] Shokralla S., Hellberg R. S., Handy S. M., King I. and Hajibabaei M. A., DNA mini-barcoding system for authentication of processed fish products, Scientific Reports 5:1-11 (2015).

[20] Agnese, J. F. and Teugels, G. G., Insight into the phylogeny of African Clariidae (Teleostei, Siluriformes): Implications for their body shape evolution, biogeography, and taxonomy, Molecular Phylogenetics and Evolution 36,546-553 (2005).

[21] Billington N. and Hebert P. D. N., Mitochondria DNA diversity in fishes and its implications for introductions, Can. J.Fish. Aquat. Sci. 48(1),88-94 (1991).

[22] Teugels G. G., Clariidae, Lévêque C., Paugy D. and Teugels G. G. (eds) Faune des Poissons d'Eaux Douces et Saumâtres de l'Afrique de l'Ouest. Vol. 2. Musée Royal de l'Afrique Central, Tervuren, and Editions de l'ORSTOM, Paris, pp 468-495, (1992).

[23] Teugels G. G., Adriaens D., Devaere S. and Musschoot T., Clariidae. In: Stiassny M. L. J., Teugels G. G. and Hopkins C. D. (eds) The Fresh and brackish water fishes of Lower Guinea, West-Central Africa, pp 653-691, (2007).

[24] Britz P. J. and Hecht T., Artificial propagation and fry production. In: Hecht T, Uys W, Britz PJ (eds) The culture of sharptooth catfish, Clarias gariepinus in Southern Africa. South African national scientific programme report No. 153, pp 36-44, (1988).

[25] Uys W., Nutrition. In: Hecht T, Uys W, Britz PJ (eds) The culture of sharptooth catfish, Clarias gariepinus in Southern Africa. South African national scientific programme report No. 153, pp 47-57, (1988).

[26] Nguenga D., Pouomogne V. and Brummett R. E., Country case study: Catfish industry in Cameroon. In: Ponzoni R. W., Nguyen N. H. (eds) Proceedings of a workshop on the development of a genetic improvement program for African catfish Clarias gariepinus. WorldFish Center conference proceedings No. 1889. The WorldFish Center, Penang, Malaysia, pp 6-14. (2008).

[27] Pouomogne V., Capture-based aquaculture of Clarias catfish: case study of the Santchou fishers in western Cameroon. In: Lovatelli A. and Holthus P. F. (eds). Capture-based aquaculture. Global overview. FAO Fisheries Technical Paper. No. 508. Rome, FAO, pp 93-108, (2008).

[28] Teugels, G. G., Legendre, M. and Hung, L. T., Preliminary results of the morphological characterization of natural population and culture strains of Clarias species (Suliriformes, Clariidae) from Vietam. In: Legendre and Antonie Pariselle (Eds). The biological diversity and aquaculture of clariid and pangasiid catfishes in South- East Asia. Proceedings of the mid-term workshop of the "catfish Asian Project". pp 2730, (1998).

Citation: Geneva Ojong Nkongho et al." Morphological and Molecular Characterization of Some Wild and Cultured Clarias (Clariidae, Siluriformes) Fish Species from Cameroon" International Journal Of Research Studies In Biosciences (Ijrsb), Vol. 7, no. 3, pp. 16-26, 2019. http://Dx.Doi.org/10.20431/2349-0365.0703003

Copyright: () 2019 Authors. This is an open-access article distributed under the terms of the Creative Commons Attribution License, which permits unrestricted use, distribution, and reproduction in any medium, provided the original author and source are credited. 